\title{
Additional records of Norwegian skate Dipturus nidarosiensis (Storm, 1881) (Pisces: Rajidae) in the Adriatic Sea
}

\author{
Igor ISAJLOVIĆ ${ }^{1}$, Jakov DULČIĆ ${ }^{1}$, Corrado PICCINETTI ${ }^{2}$, Nedo VRGOČ ${ }^{1}$, \\ Chiara MANFREDI ${ }^{2}$ and Branko DRAGIČEVIĆ ${ }^{1^{*}}$
}

\author{
${ }^{1}$ Institute of Oceanography and Fisheries, Šetalište Ivana Meštrovića 63, 21000 Split, Croatia \\ ${ }^{2}$ Laboratorio di Biologia Marina e Pesca di Fano, Dip.to Bi.Ge.A. - Università di Bologna, \\ Viale Adriatico 1/n, 61311 Fano (PU), Italy \\ *Corresponding author, e-mail: brankod@izor.hr
}

\begin{abstract}
Additional records of the Norwegian skate Dipturus nidarosiensis (Storm, 1881) from the Adriatic Sea are reported. Two specimens were collected in the southern Adriatic Pit in 2008 and 2010, respectively. The records reported herein improve our knowledge on the distribution of a rarely encountered, deep water species D. nidarosiensis, whose presence has only recently been confirmed in the Mediterranean Sea.
\end{abstract}

Key words: Dipturus nidarosiensis, records findings, Mediterranean Sea, Adriatic Sea

\section{INTRODUCTION}

The Mediterranean Sea is considered a global marine biodiversity hotspot and it is inhabited by at least 89 chondrichthyan species, which corresponds to about $7 \%$ of the global species diversity of this group of fishes (SERENA, 2005; BRADAI et al., 2012). Several non-native and range expanding elasmobranch species have recently been recorded in the Mediterranean Sea, for example, Galeocerdo cuvieri, Rhizoprinodon acutus, Himantura uarnak, etc. (BRADAI et al., 2012; ZENETOS et al., 2011, 2012; GOLANI et al., 2019). The Norwegian Skate, Dipturus nidarosiensis is known to be distributed in the Northeast Atlantic from Iceland and Norway in the north to the Bay of Biscay in the south where it is considered uncommon (STEHMANN et al., 2015). In recent studies, the presence of this species has also been ascertained in the Mediterranean (CANNAS et al., 2010; FOLLESA et al., 2012; RAMIREZ-AMARO et al., 2017; CARBONARA et al., 2019). According to the IUCN classification, this species' status is evaluated as "Near Threatened (NT)" (STEHMANN et al., 2015). Misidentifications of species of the genus Dipturus are well documented and long-term taxonomic confusion can hamper the effectiveness of conservation efforts (IGLESIAS et al., 2010). In the Southern Adriatic and Western Ionian Sea, the presence of Dipturus nidarosiensis has been recently confirmed by CARBONARA et al. (2019). It represents the third species of genus Dipturus so far recorded in the Adriatic Sea, the two other species being Dipturus batis (Linnaeus, 1758) and Dipturus oxyrinchus (Linnaeus, 1758) (LIPEJ \& DULČIĆ, 2010). 
In the present study, we report additional records of $D$. nidarosiensis in the Adriatic Sea.

\section{MATERIALS AND METHODS}

Two female specimens of the Norwegian skate Dipturus nidarosiensis were caught during FAO AdriaMed Deep Sea Expedition in 2008 and 2010 on two locations in the south Adriatic Pit $\left(42^{\circ} 02,920 \mathrm{~N} ; 18^{\circ} 22,66 \mathrm{E}\right.$ and $41^{\circ} 49,22 \mathrm{~N}$; $17^{\circ} 38,94$ E, respectively, Fig 1.) with the deep water bottom otter trawl and longline, respectively. Both specimens were photographed (Fig. 2), identified and the tissue samples from both specimens were stored in the Ravenna Laboratory, Department of Biological, Geological and Environmental Sciences, University of Bologna, Italy. Both specimens were measured, weighed and dissected for determination of sex and maturity stage according to MEDITS survey protocol (BERTRAND et al., 2002). During the 2008 survey, an additional specimen, identified on the basis of morphological characters (i.e. pointed snout, dark underside) was caught on the bottom set longline, but it got unhooked and managed to escape before landing on board.

Identification was carried out following the identification key provided by EBERT \& STEHMANN (2013). In reporting the occurrence of $D$. nidarosiensis in the Adriatic Sea, we followed the protocol suggested by BELLO et al. (2014).

\section{RESULTS AND DISCUSSION}

Basic biological data of the two specimens as well as additional data regarding their capture are presented in Table 1.

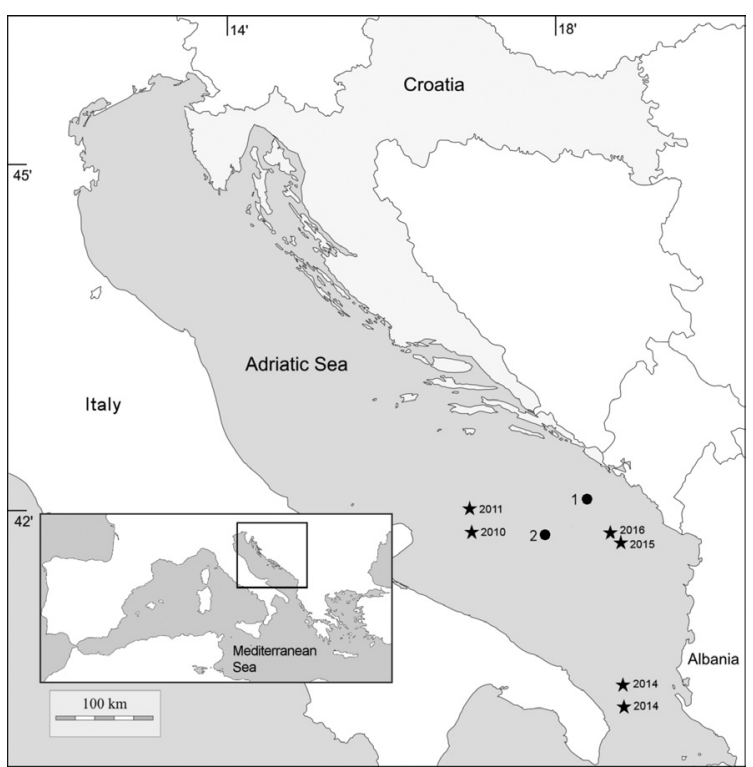

Fig 1. Locations of the captures of D. nidarosiensis in the Adriatic Sea. Black dots indicate locations of the specimens presented in this study. Numbers correspond to the specimens presented in Table 1. Black stars indicate locations of the specimens collected in the study by CARBONARA et al. (2019) with indication of the year of collection

Both individuals shared the same general body description. The body has the shape of a broad rhomboidal disc, with moderately double concave anterior margins and acute outer corners; snout long and pointed; tail relatively short and gradually tapering to a tip; two small dorsal fins, similar in size and clearly separated; dorsal surface of the disc mostly smooth except for the median row of small thorns along the tail to first dorsal fin; prickly areas on the head and anterior disc margins and small thornlets on orbital rims; ventral part almost entirely covered with coarse dermal denticles. Color dorsally plain dark greyish-brown, somewhat darker on the disc

Table 1. Total length, weight, disc width, sex, maturity of two specimens of D. nidarosiensis from the Adriatic Sea

\begin{tabular}{|c|c|c|c|c|c|c|c|c|}
\hline Specimen & $\begin{array}{c}\text { Total } \\
\text { Weight }(\mathrm{g})\end{array}$ & $\begin{array}{c}\text { Total } \\
\text { length } \\
(\mathrm{mm})\end{array}$ & $\begin{array}{c}\text { Disc } \\
\text { width } \\
(\mathrm{mm})\end{array}$ & Sex & $\begin{array}{c}\text { Maturity } \\
\text { Stage } \\
\text { (MEDITS } \\
\text { scale) }\end{array}$ & Depth & Date & Gear \\
\hline 1. & 3210 & 930 & 670 & $\mathrm{~F}$ & 1 & 1080 & 21.8 .2008 & Trawl \\
\hline 2. & 3500 & 940 & 680 & $\mathrm{~F}$ & 1 & 1144 & 12.5 .2010 & Longline \\
\hline
\end{tabular}



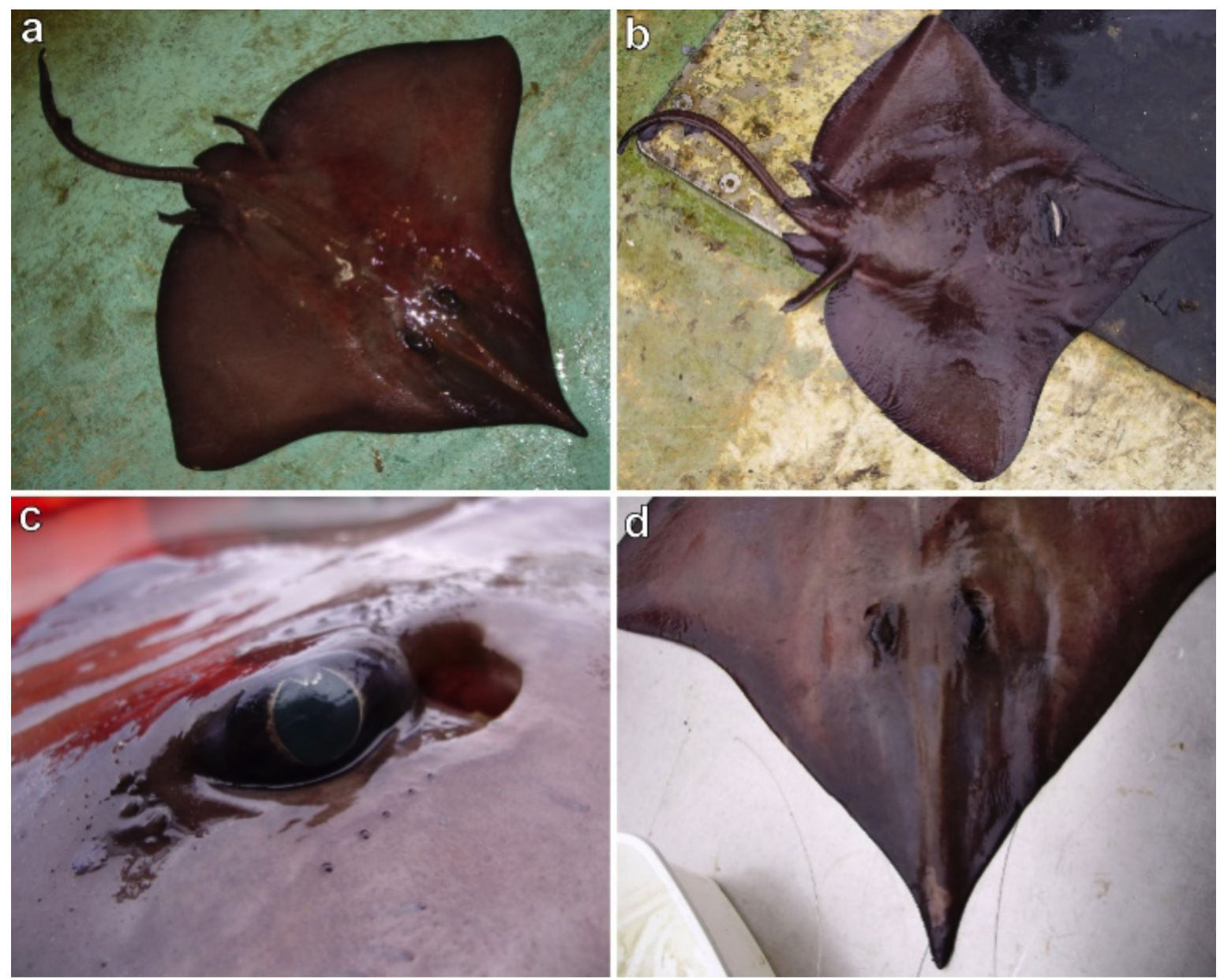

Fig 2. Photos of the two specimens of Dipturus nidarosiensis collected in the southern Adriatic Sea. Photos description as follows: a) dorsal view of specimen 1; b) ventral view of specimen 2; c) closeup of the left eye and spiracle of specimen 2 ; d) closeup of anterior part with rostrum of specimen 2.

See Table 1 for additional details

margins; underside darker brown and covered by a thick black mucus layer. This description is in agreement with that given by EBERT \& STEHMANN (2013).

The first record of $D$. nidarosiensis in the Adriatic Sea was reported by CARBONARA et al. (2019) on the basis of six specimens collected in the area around the pit of Bari at depths ranging from 320-720 meters in the period from 2011 to 2016 (Fig 1.). Total lengths of specimens ranged from 305 to $1422 \mathrm{~mm}$. The authors also reported the occurrence of two specimens from the northwest part of the Ionian Sea. The identification of the specimens from that study was established both on the basis of molecular and morphological evidence. It should be noted that, according to CARBONARA et al. (2019), two Adriatic speci- mens from the mentioned study were already previously analyzed by CARIANI et al. (2017), but the latter authors did not specify that those specimens had been collected in the Adriatic basin. The first Mediterranean record of the species, confirmed by molecular and morphological evidence, was reported by CANNAS et al. (2010). That record considered 14 specimens caught off Sardinia in the western central Mediterranean Sea at depths from 600-1420 m, which were collected in the period from 2005 to 2008. It should be noted that EBERT \& STEHMANN (2013) considered individuals collected off Sardinia as morphologically distinct from North Atlantic $D$. nidarosiensis specimens and even considered it as members of a yet undescribed species (presented as Dipturus sp.). Additionally, FOLLESA et 
al. (2012) reported some reproductive parameters as well as stomach contents of 23 specimens collected off Sardinia from 2005 to 2011. Eight specimens of $D$. nidarosiensis, whose identification was supported both by molecular and morphological evidence, were collected in the Alboran Sea in 2012, 2013 and 2016, between 620 and $819 \mathrm{~m}$ depth (RAMIREZ-AMARO et al., 2017). In 2017, a juvenile specimen of D. nidarosiensis, collected from the Strait of Sicily, was reported by GERACI et al. (2019), thus confirming the presence of this species in that area. It should be noted that a previous finding of an egg case, attributed to D. nidarosiensis on the basis of the egg case morphology, already indicated its presence in the area (MASSI et al., 2017).

Both female specimens from our study were immature (MEDITS scale 1). According to FOLLESA et al. (2012) length range at which females reach maturity is $1270-1420 \mathrm{~mm}$ (TL). CARBONARA et al., (2019) reported a smaller mature female specimen (1194 mm TL) collected in the Adriatic Sea. Males of this species reach maturity at smaller lengths than females (1180 mm TL) (FOLLESA et al., 2012).

Both of our specimens were found at greater depths than those previously reported in the Adriatic Sea. CARBONARA et al. (2019) noted that sub-adults and adults occur at lower depths, while segregation of juveniles occurred only in the upper part of the slope. FOLLESA et al. (2012) noted that immature and maturing female speci- mens were found in a wide bathymetric range in the waters around Sardinia, while mature females were found at lower depths (550-600 $\mathrm{m})$.

We point out that the capture of our specimens in 2008 and 2010, respectively, occurred earlier than those reported and discussed by CARBONARA et al. (2019). Furthermore, the specimen from 2008 represents one of the earliest Mediterranean records, preceded only by those reported by CANNAS et al. (2010). As already suggested by CANNAS et al. (2010) and CARBONARA et al. (2019), presence of this species in the Mediterranean has probably gone unnoticed due to two main reasons. One may be the misidentification with other species in the genus Dipturus and the other one its high depth and specific habitat preference which only partially overlap with fishery grounds, so that the possibility of being caught by the fishing fleets is reduced. Future studies of the deep Adriatic should shed more light on the biology and ecology as well as on other aspects of this poorly known species.

\section{ACKNOWLEDGEMENTS}

We are thankful to FAO ADRIAMED Deep Sea Expedition for providing the specimens. This work has been fully supported by the CROATIAN SCIENCE FOUNDATION (HRZZ) under project IP-2016-06-5251.

\section{REFERENCES}

BRADAI, M.N., B. SAIDI \& S. ENAJJAR. 2012. Elasmobranchs of the Mediterranean and Black Sea: Status, Ecology and Biology. Bibliographic Analysis. FAO, Rome.

BELLO, G., R. CAUSSE, L. LIPEJ, J. DULČIĆ. 2014. A proposed best practice approach to overcome unverified and unverifiable "first records" in ichthyology. Cybium, 38 (1): 9-14.

BERTRAND, J.A, L. GIL de SOLA, C. PAPACONSTANTINOU, G. RELINI \& A. SOUPLET. 2002. The general specifications of the Medits surveys. Sci. Mar., 66 (2): 9-17.
CANNAS, R., M.C. FOLLESA, S. CABIDDU, C. PORCU, S. SALAVADORI, S.P. IGLESIAS, A.M. DEJANA \& A. CAU. 2010. Molecular and morphological evidence of the occurrence of the Norwegian skat Dipturus nidarosiensis (Storm, 1881) in the Mediterranean Sea. Mar. Biol. Res., 6 (4): 341-350.

CARBONARA, P., R. CANNAS, M. DONNALOIA, R. MELIS, C. PORCU, M.T. SPEDICATO, W. ZUPA \& M.C. FOLLESA. 2019. On the presence of Dipturus nidarosiensis (Storm, 1881) in the Central Mediterranean area. Peer J, 7: e7009: $1-20$. 
CARIANI, A., S. MESSINETTI, A. FERRARI, M. ARCUELO, J.J. BONELLO, L. BONICI, R. CANNAS, P. CARBONARA, A. CAU, C. CHARILAOU, N.E. OUAMARU, F. FIORENTINO, M.C. FOLLESA, G. GAROFALO, D. GOLANI, I. GUARNIERO, R. HANNER, F. HEMIDA, O. KADA, S.L. BRUTO, C. MANCUSI, G. MONEY, P.J. SCHEMBRI, F. SERENA, I. SION, M. STAGIONI, A. TURSI, N. VRGOČ, D. STEINKE \& F. TINTI. 2017. Improving the Conservation of Mediterranean Chondrichthyans: The ELASMOMED DNA Barcode Reference Library. PLoS ONE, 12 (1): e0170244. doi:10.1371/journal. pone. 0170244

EBERT, D.A. \& M. STEHMANN. 2013. Sharks, batoids, and chimaeras of the North Atlantic. FAO Species Catalogue for Fishery Purposes, 7. Rome, FAO: 523 pp.

FOLLESA, M.C., R. CANNAS, S. CABIDDU, A. CAU, A. MULAS, C. PORCU \& A. CAU. 2012. Preliminary observations of the reproductive biology and diet for the Norwegian skate Dipturus nidarosiensis (Rajidae) from the Central Western Mediterranean Sea. Cybium, 36 (3): 473-477.

FROESE, R. \& D. PAULY. Editors. 2019. FishBase. World Wide Web electronic publication. www.fishbase.org, version (02/2019).

GERACI, M.L., M. DI LORENZO, F. FALSONE, D. SCANNELLA, F. DI MAIO, F. COLLOCA, S. VITALE, F. SERENA. 2019. The occurrence of Norwegian skate, Dipturus nidarosiensis (Elasmobranchii: Rajiformes: Rajidae), in the Strait of Sicily, central Mediterranean. Acta Ichthyol. Piscat., 49 (2): 203-208.

GOLANI, D., E. MASSUTI, L. ORSI-RELINI, J. DULČIĆ \& E. AZZURRO. 2019. CIESM Atlas of Exotic Fishes in the Mediterranean Sea http:/www. ciesm.org/atlas/appendix1.html (04/2019)

IGLESIAS, S.P., L. TOULHOAT \& D.Y. SELLOS. 2010. Taxonomic confusion and market mislabelling of threatened skates: important consequences for their conservation status. Aquat Conserv., 20(3): 319-333.

LIPEJ, L. \& J. DULČIĆ. 2010. Checklist of the Adriatic Sea Fishes. Zootaxa, 2589: 1-92.

MASSI, D., A. TITONE, C. MANCUSI, F. SERENA, \& F. FIORENTINO. 2017. First finding of Diptu- rus nidarosiensis (Storm, 1881) (Chondrichthyes: Elasmobranchii, Rajidae) egg capsule in the Strait of Sicily. Biologia Marina Mediterranea, 24 (1): 194-195.

PSOMADAKIS, P.N., S. GIUSTINO \& M. VACCHI. 2012. Mediterranean fish biodiversity: an undated inventory with focus on the Ligurian and Tyrrhenian seas. Zootaxa, 3263: 1-46.

RAMIREZ-AMARO, S., F. ORDINES, M.A. PUERTO, C. GARCIA, C. RAMON, B. TERRASA \& E. MASSUTI. 2017. New morphological and molecular evidence confirm the presence of the Norwegian skate Dipturus nidarosiensis (Storm, 1881) in the Mediterranean Sea and extend its distribution to the western basin. Medit. Mar. Sci., 18 (2): 251-259.

SERENA, F. 2005. Field identification Guide to the sharks and rays of the Mediterranean and Black Sea. FAO, Species Identification Guide for Fishery Purposes. FAO: 97 pp.

STEHMANN, M.F.W., J. ELLIS, R. WALLS \& A. LYNGHAMMAR. 2015. Dipturus nidarosiensis. The IUCN Red List of Threatened Species. http://www.iucnredlist.org/details/161729/0 (Accessed 16 April 2019).

ZENETOS, A., S. GOFAS, M. VERLAQUE, M.E. ÇINAR, J.E. GARCIA-RASO, C.N. BIANCHI, C. MORRI, E. AZZURRO, M. BILECENOGLU, C. FROGLIA, I. SIOKOU, D. VIOLANTI, A. SFRISOI, G. SAN MARTIN, A. GIANGRANDE, T. KATAGAN, E. BALLESTEROS, A. RAMOS-ESPLA, F. MASTROTOTARO, O. OCANA, A. ZINGONE, M.C. GAMBI \& N. STREFTARIS. 2011. Alien species in the Mediterranean Sea by 2010. 2011. A contribution to the application of European Union's Marine Strategy Framework Directive (MSFD). Part I. Spatial distribution. Medit. Mar. Sci., 11 (2): 509-514.

ZENETOS, A., S. GOFAS, C. MORRI, A. ROSSO, D. VIOLANTI, J.E. GARCIA RASO, M.E. CINAR, A. ALMOGI-LABIN, A.S ATES, E. AZZURRO, E. BALLESTROS, C.N. BIANCHI, M. BILECENOGLU, M.C. GAMBI, A. GIANGRANDE, C. GRAVILI, O. HYAMS-KAPHZAN, P.K. KARACHLE, S. KATSANEVAKIS, L. LIPEJ, F. MASTROTOTARO, F. MINEUR, M.A. PANUCCI-PAPADOPOULOU, A. RAMOS ESPLA, C. SALAS, G. SAN MARTIN, A. SFRISO, N. STREFTARIS \& M. VERLAQUE. 2012. 
Alien species in the Mediterranean Sea by 2012. A contribution to the application of European Union's Marine Strategy Frame- work Directive (MSFD). Part 2. Introduction trends and pathways. Medit. Mar. Sci., 13 (2): $328-352$.

Received: 28 April 2020

Accepted: 4 June 2020

\title{
Novi nalazi crne voline Dipturus nidarosiensis (Storm, 1881) (Pisces: Rajidae) iz Jadranskoga mora
}

\author{
Igor ISAJLOVIĆ, Jakov DULČIĆ, Corrado PICCINETTI, Nedo VRGOČ, \\ Chiara MANFREDI i Branko DRAGIČEVIĆ* \\ *Kontakt, e-pošta: brankod@izor.hr
}

\section{SAŽETAK}

U radu su opisani novi nalazi crne voline Dipturus nidarosiensis (Storm, 1881) iz Jadranskoga mora. Dva primjerka ulovljena su na području Južnojadranske kotline 2008. odnosno 2010. godine.

Ovi nalazi proširuju saznanja o distribuciji ove rijetke dubokomorske vrste čija je prisutnost u Sredozemnom moru tek nedavno utvrđena.

Ključne riječi: Dipturus nidarosiensis, novi nalazi, Sredozemno more, Jadransko more 